\title{
研究論交
}

\section{Studies on Countercurrent Extraction of Radionuclides, (II)}

\author{
Separation of ${ }^{233} \mathrm{U}$ and ${ }^{233} \mathrm{~Pa}$ from Irradiated Thorium \\ TBPO-HCl System
}

\author{
By Tomitaro ISHIMORI* and Hassan M. SAMMOUR**
}

\begin{abstract}
Solvent extraction of ${ }^{233} \mathrm{U}$ and ${ }^{233} \mathrm{~Pa}$ from irradiated thorium was carried out by the discontinuous countercurrent extraction technique in hydrochloric acid solutions of various concentrations with tri-n-butyl phosphine oxide (TBPO). The results showed that $1 \mathrm{~N}$ $\mathrm{HCl}$ is the best medium to affect such separation, with $1 \%$ TBPO-tolvene solution. Higher decontamination factor for uranium fraction and clean separation of protactinium from thorium were obtained under the above mentioned conditions.
\end{abstract}

\section{INTRODUCTION}

In a previous communication ${ }^{(1)}$, application of the discontinuous countercurrent solvent extraction technique to problems of radiochemical separation of fission products has been described, and satisfactory separations could be achieved by such technique.

One of the important radiochemical separations worth of studying now and which attracted the attention of several investigators in the last twenty years, is the isolation of ${ }^{233} \mathrm{U}$ and ${ }^{233} \mathrm{~Pa}$ from neutron irradiated thorium. The importance of such separation lies in the preparation of the pure fissionable ${ }^{233} \mathrm{U}$ isotope, which is the third source of nuclear energy other than the already known two sources ${ }^{235} \mathrm{U}$ and ${ }^{239} \mathrm{Pu}$.

As is well known ${ }^{233} \mathrm{U}$ is formed by neutron bombardment of thorium in nuclear reactors according to the following scheme :

$$
{ }_{90}^{232} \mathrm{Th}+n \rightarrow{ }_{90}^{233} \mathrm{Th} \frac{\beta^{-}}{23.5 \mathrm{~min}} \rightarrow{ }_{91}^{233} \mathrm{~Pa} \frac{\beta^{-}}{27.4 \mathrm{~d}}{ }_{92}^{233} \mathrm{U}
$$

Three methods have been usually described for the separation of trace amounts of ${ }^{233} \mathrm{U}$ from small quantity of ${ }^{233} \mathrm{~Pa}$ and gross amount of thorium.

(1) Separation of uranium directly after complete decay of protactinium

(2) Separation of both ${ }^{233} \mathrm{U}$ and ${ }^{233} \mathrm{~Pa}$ from thorium after the usual cooling period of irradiated thorium targets followed by separation of ${ }^{233} \mathrm{~Pa}$ from ${ }^{233} \mathrm{U}$

(3) Direct separation of ${ }^{233} \mathrm{~Pa}$ only after short irradiation period; the separated nuclide is then allowed to decay into ${ }^{233} \mathrm{U}$.

Several processes for the chemical separation of protactinium and for uranium recovery have been developed, including fluoride volatilization $^{(2)}$, manganese dioxide precipitation ${ }^{(3)}$, iodate precipitation ${ }^{(4)}$, solvent extraction ${ }^{(5) \sim(14)}$ and ion exchange ${ }^{(15) \sim(18)}$.

Solvent etxraction techniques had been always preferred due to their simplicity, selectivity and high recovery of the products, also they can be easily operated by remote control for large scale production, as is occurring in the famous Thorex Process ${ }^{(19)}$. As regards the type of solvent used as extractant diethyl ether ${ }^{(20) \sim(23)}$, was generally accepted as a good solvent due to its low boiling point and high solubility of uranium in it. A survey of solvents for extraction of ${ }^{233} \mathrm{U}$ and ${ }^{233} \mathrm{~Pa}$ from neutron irradiated thorium had been made by Hyde and Wolf ${ }^{(24)}$.

Researches carried out for the discovery

* 石森富太郎。Chem. Div., Japan Atomic Energy Res. Inst.（日本原子力研究所化学部）

** Chem. Dept., Faculty of Science, Cairo Univ., UAR. (カイロ大学) 
of new solvents for uranium extraction, proved that symmetrical phosphine oxides of which tri- $n$-butyl phosphine oxide (TBPO) is a typical member, are strongest extractors for uranium in nitrate and chloride media ${ }^{(25) \sim(28)}$. Recently, Ishimori, et al. ${ }^{(29)}$ have found that uranium is easily extracted with $1 \%$ tributyl phosphine oxide in toluene from hydrochloric acid medium, while thorium is hardly extracted.

Most of the above mentioned solvent extraction works have been carried out by simple batch techniques. However some semicontinuous solvent extractors ${ }^{(30)}$, remotely controlled laboratory scale apparatus ${ }^{(22)}$, batchby-batch extraction for isolating milligram quantities of ${ }^{233} \mathrm{U}$, and pilot plants for purification of thorium nitrate by countercurrent extraction $^{(31)}$ were developed.

In this investigation the discontinuous countercurrent solvent extraction technique is applied for the separation of ${ }^{233} \mathrm{U}$ and ${ }^{233} \mathrm{~Pa}$ from irradiated thorium using 1 or $2 \%$ tributyl phosphine oxide (in toluene) from hydrochloric acid medium of various concentrations. The aim is to test the feasibility of such separation with this new technique and estab. lish the best conditions for maximum efficiency.

\section{Experimental}

\section{Countercurrent extraction apparatus}

The countercurrent apparatus used in this investigation was similar in principle to that previously used by Craig and coworkers ${ }^{(32)}$ with some minor modifications and was described in detail in our previous publication ${ }^{(1)}$. The main parts of the device are the 60 glass equilibration cell-extractor, the feeding device and the fraction collector.

\section{(1) Working procedure}

After filling the extractor with hydrochloric acid of the required concentration, a definite volume of the irradiated thorium solution in hydrochloric acid was cautiously injected in the first equilibration cell, and the process of extraction was then allowed to go automatically. Preliminary experiments showed that 30 portions of the organic solvent were quite enough to achieve a good separation.

\section{(2) Materials}

Chemically pure materials were always employed. The hydrochloric acid was used after proper dilution to the required concentration. Tri-n-butyl phosphine oxide was a white crystalline product (m.p. $62^{\circ} \sim 63^{\circ} \mathrm{C}$ ) provided by Tama Kagaku Co. Ltd. The dilute solution of TBPO was prepared by dissolving a definite weight of the substance in the required volume of the extra-pure toluene.

Five grams of thorium dioxide (Mitsui Kinzoku Kogyo Chemicals) were irradiated in JRR-1 for $173 \mathrm{hr}$ at a neutron flux of $10^{11}$ $\mathrm{n} / \mathrm{cm}^{2} \cdot \mathrm{sec}$. After cooling for 10 months, the irradiated thorium target was dissolved in 50 $\mathrm{m} l$ concentrated hydrochloric acid containing a small amount of potassium fluoride $(\sim 0.01 \mathrm{M})$ which enhances the dissolution ${ }^{(29)}$. The process was carried out in a $100 \mathrm{~m} l$ pyrex flask equipped with a reflux condenser and heated on a hot plate. Complete dissolution was observed after $2 \mathrm{hr}$. After dissolution of thorium dioxide the solution was evaporated under an infrared lamp and the acidity was adjusted with hydrochloric acid of the required concentration.

\section{Radiochemical analysis}

Gamma-counting for ${ }^{233} \mathrm{~Pa}$ carried out by a Philips BW 4032 electronic was counter and a well-type $\mathrm{NaI}$ thallium activated crystal scintillator. The whole volume of each of the aqueous or organic fraction was used for counting.

Alpha-counting was made by careful plating of 100 or $250 \lambda$ of the organic phases, on platinum planchets $2.5 \mathrm{~cm}$ in diameter in an induction furnace. Care was taken not to leave any residue on the plate otherwise $\alpha$. counting would be greatly reduced. The plates were then counted in a gas flow proportional counter, composed of an RCL decade scaler model 20302 in combination with an RCL pulse amplifier-high voltage supply MK 15 model 1A. The working voltage was $2,900 \mathrm{~V}$.

Gamma-ray spectrograms were obtained by means of an RCL 256 multichannel $\gamma$ ray spectrometer. 


\section{Results and Discussion}

The results of countercurrent separation of ${ }^{233} \mathrm{U}-{ }^{233} \mathrm{~Pa}$-Th mixture in hydrochloric acid medium of varying concentrations and using the 1 or $2 \%$ TBPO toluene solution are given in Figs. 1, 2, 3 and 4. In each figure the vertical axis represents counts per minute ( $\gamma$ or $\alpha$-counts) and the horizontal one represents the tube number. Two patterns are

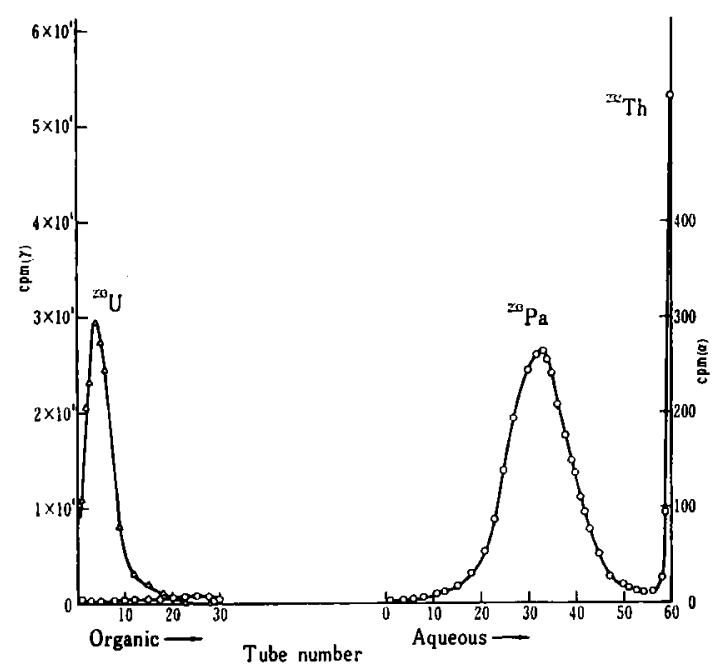

Fig. $11 \%$ TBPO- $1 \mathrm{NHCL}(D . F .=113)$

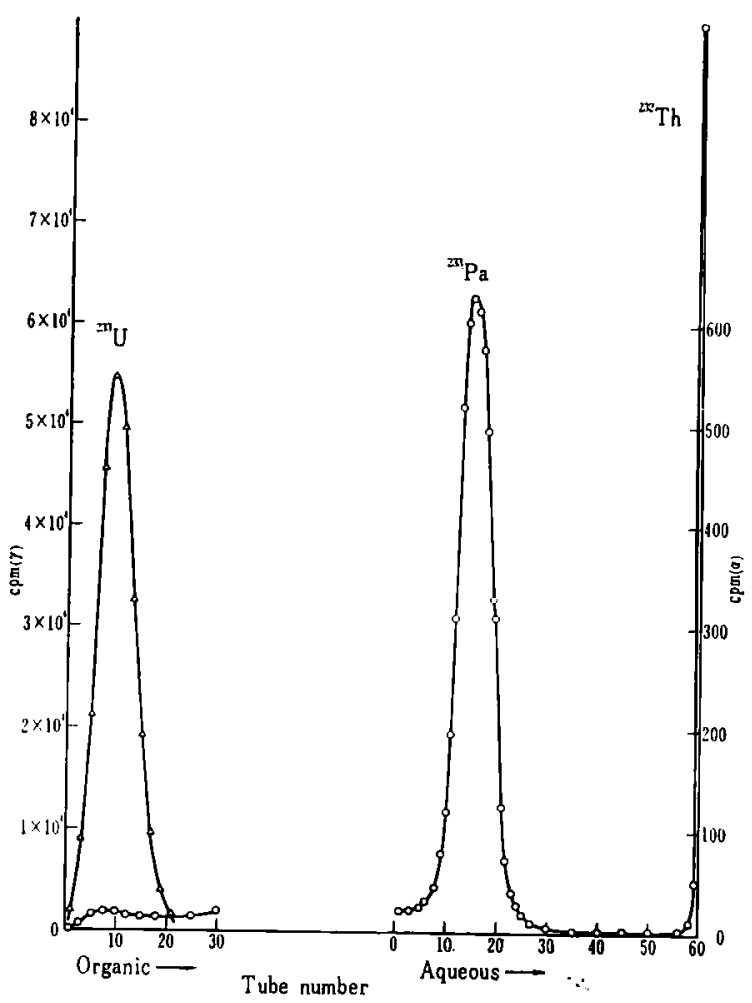

Fig. $21 \%$ TBPO- $2 \mathrm{NHCL}(D . F .=39)$ generally represented on the figure, the left hand side one is that for solvent and the right hand side one for aqueous. To make the situation clear, the solvent fraction number one is that firstly sent in the extraction train and consequently that which was received first in the fraction collector. Aqueous fraction No. 1 is that contained in the last equilibration cell of the extractor from which the solvent fractions flow out into the fraction collector; aqueous fraction No. 60 represents that which was contained in the equilibration cell where the radioactive materials have been

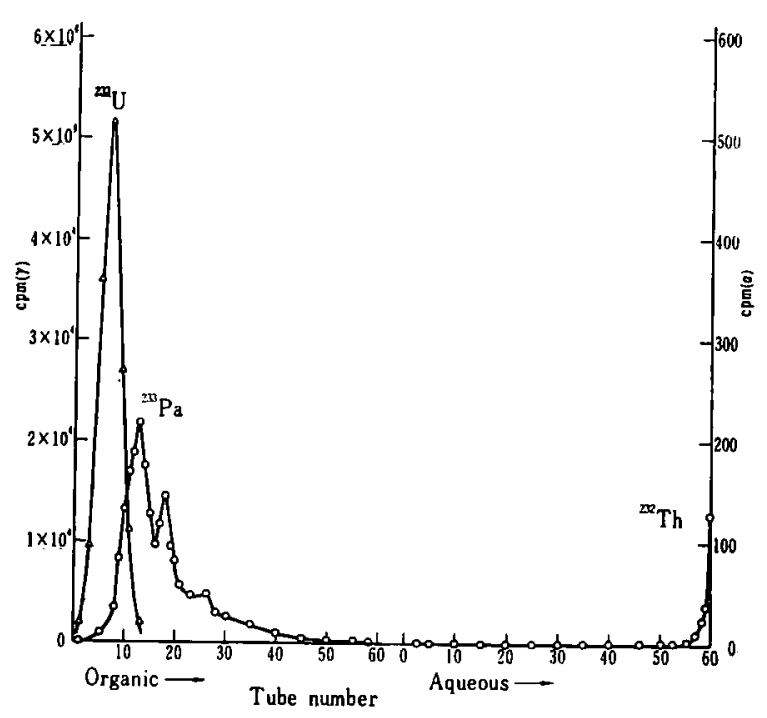

Fig. $32 \%$ TBPO- 3 NHCL

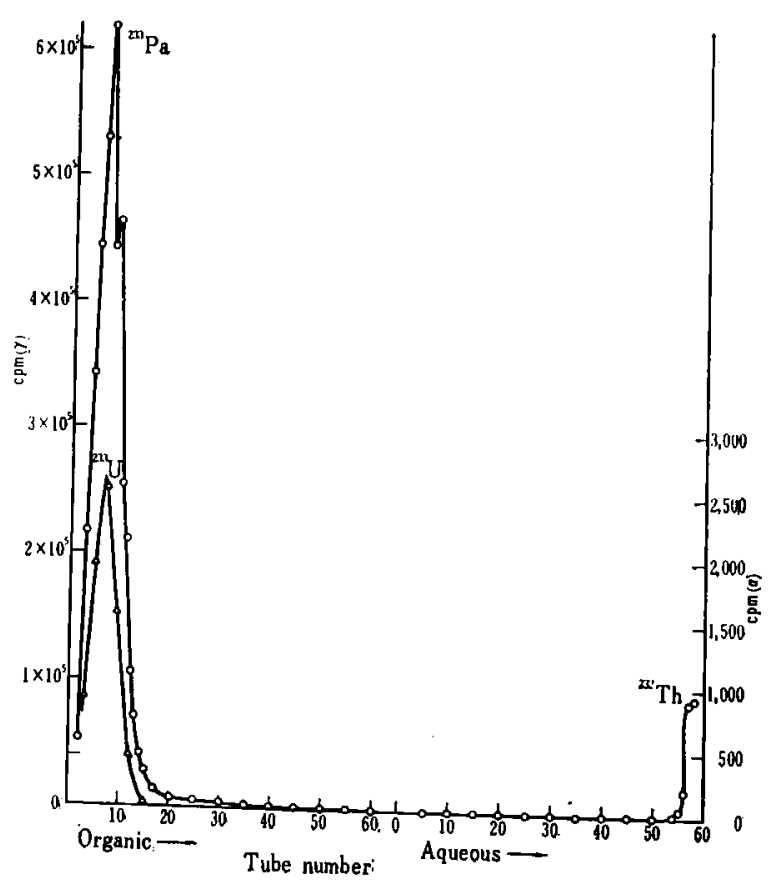

Fig. $42 \%$ TBPO- 6 N HCL 
added. The $\gamma$-or $\alpha$-activity represented on the vertical axis denotes the total activity obtained in the aqueous or solvent fractions.

As shown by these figures, excellent separation could be affected in $1 \mathrm{NHCl}$ with $1 \%$ TBPO. At such acid concentration uranium only is extracted in the organic phase, the peak of extraction corresponds to the 4 th organic fraction and most of uranium activity becomes concentrated in the first 10 tubes; the $\alpha$-activity after tube No. 20 becomes almost nil. That was the reason why 30 organic portions only were sent in the extractor*. ${ }^{233} \mathrm{~Pa}$ was found to be almost concentrated in the aqueous phase; the greater part of its activity was found in tubes Nos. $20 \sim 45$ as indicated by the position of the peak in the pattern representing the aqueous fractions in the graph. Thorium was poorly extracted under such conditions and remained distributed in the last 3 aqueous fractions; namely in tubes Nos. 58,59 and 60. This has been proved experimentally by precipitation of thorium hydroxide with ammonium hydroxide solution in the following way; $250 \lambda$ aliquot portions of each of the last 4 aqueous fractions were placed in 4 microcentrifuge tubes each containing a little quantity of distilled water. A definite volume of dil. (2N) $\mathrm{NH}_{4} \mathrm{OH}$ solution sufficient for precipitation of thorium hydroxide was added to each tube. The solution inside was then made up to a definite volume by a distilled water and the tubes were left to settle for an overnight.

The photograph of the precipitates shown in Plate 1 indicates clearly the gradual distribution of thorium in the last 3 equilibration

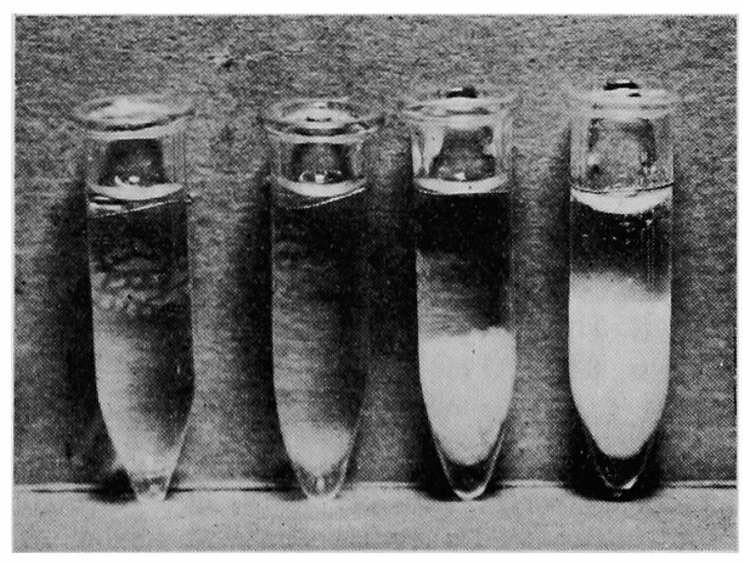

Plate 1 cells Nos. 58,59, and 60 of the extractor. No thorium was found in the other aqeous fractions except in these 3 last tubes.

Slight amount of ${ }^{233} \mathrm{~Pa}$ was found to contaminate the uranium fractions, but the decontamination factor for the uranium-extraction process (i.e. ratio of total $\gamma$-activity in organic and aqueous fractions to $\gamma$-activity found in the first 15 organic fractions in which all uranium was extracted) was high and amounted to 113 . The $\gamma$ ray spectrograms for pilot samples of protactinium and thorium fractions (Figs. 5 and 6) showed in the first case the two usual photopeaks at $\sim 0.08$ and $0.313 \mathrm{MeV}$ characteristic for ${ }^{233} \mathrm{~Pa}$ while in the latter case one definite photopeak at 0.2 $\mathrm{MeV}$ and several other slight peaks at 0.37 , 0.75 and $1.25 \mathrm{MeV}$ were displayed. These photopeaks may be ascribed to daughters of thorium e.g. ${ }^{212} \mathrm{~Pb}(\mathrm{Th} \mathrm{B}),{ }^{212} \mathrm{Bi}$ (Th C), ${ }^{208} \mathrm{Tl}$ $\left(\mathrm{Th} \mathrm{C}^{\prime \prime}\right), \cdots$ etc. The absence of the characteristic ${ }^{233} \mathrm{~Pa}$ peaks in the latter spectrogram indicates the effectiveness of separation of protactinium from thorium under such conditions.

The results of separation in the $1 \mathrm{~N}$ and $2 \mathrm{~N}$ hydrochloric acid solutions are comparable and competing with each other. For example although a sharper and narrower peak for protactinium extraction was obtained in the aqueous phase in the $2 \mathrm{~N}$ acid, yet the decontamination factor for the uranium fraction is smaller than in the $1 \mathrm{~N}$ hydrochloric acid. This is quite expected since as proved by Ishimori, et al. ${ }^{(33)}$, the $K_{d}$ values for protactinium under comparable conditions of extraction as those used in the present work, increase roughly by 2 times with increasing hydrochloric acid concentration from 1 to $2 \mathrm{~N}$. The $K_{d}$ values for thorium are hardly affected by such increase in acidity. Therefore tho contamination of uranium with protactinium is much less and the separation of the latter from thorium is better with the $1 \%$ TBPO extraction in $1 \mathrm{~N} \mathrm{HCl}$ rather than in hydrochloric acid solutions of higher concentrations. The same conclusions may be arrived at from

* The $\alpha$ activity of uranium was confined to the solvent fractions only and no activity at all was found in the aqueous fractions. 


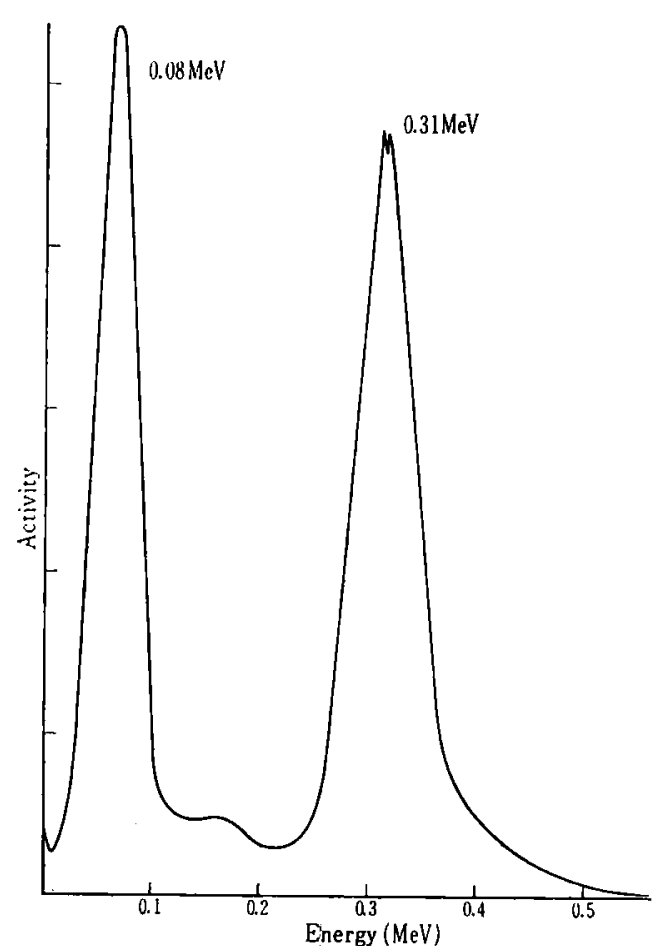

Fig. $5 \gamma$ ray spectrum for protactinium fraction

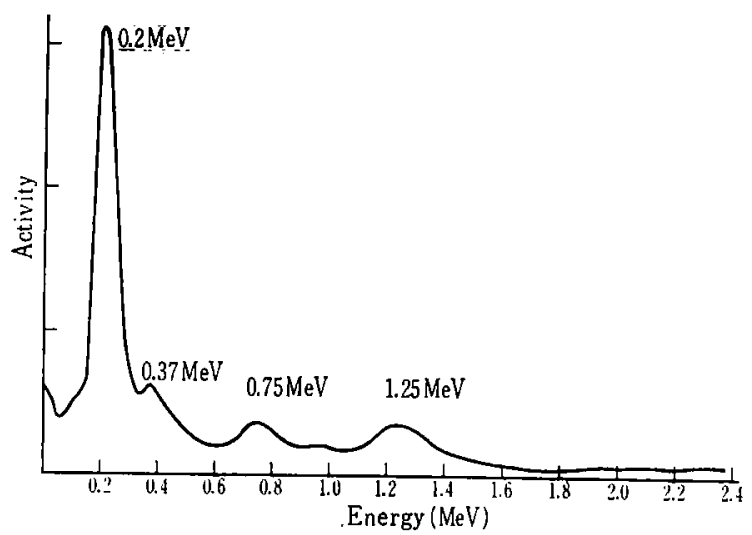

Fig. $6 \gamma$ ray spectrum for thorium fraction

consideration of the results obtained in $3 \mathrm{~N}$ or $6 \mathrm{~N}$ hydrochloric acid solutions shown in Figs. 3 and 4 respectively. The results clearly indicate that almost all protactinium is extracted together with uranium in the TBPO phase; the protactinium $K_{d}$ value increases by more than 100 times as the concentration of hydrochloric acid changes from 1 to $6 \mathrm{~N}$.

The countercurrent separation of the mixture was repeated in $0.2 \mathrm{~N} \mathrm{HCl}$ medium, but the results obtained were not satisfactory, and hence were not indicated.

In the light of the above findings countercurreant separation of ${ }^{233} \mathrm{U},{ }^{233} \mathrm{~Pa}$ from irradiated thorium proved to be much more suitable than batch extraction due to higher efficiency and adaptability of the former to continuous operation. The method employed may be used for the preparation of small samples of very pure ${ }^{233} \mathrm{U}$ especially after short periods of irradiation by allowing decay of the extra pure ${ }^{233} \mathrm{~Pa}$ fraction. TBPO will completely extract all uranium present resulting either from protactinium decay or originally present as natural uranium impurity in the thorium target.

The feasibility of separation of ${ }^{233} \mathrm{U},{ }^{233} \mathrm{~Pa}$ from thorium by the method described may also depend on the amount of uranium present; in other words on the relative magnitude of the distribution coefficients of the components of the mixture under the prevailing experimental conditions.

The authors wish to express their gratitude to Profs. Kenjiro Kimura and Toshio Nakai for the facilities they offered during carrying out of this work. The assistance of Messrs. $\mathrm{K}$. Kimura and $\mathrm{K}$. Watanabe is also appreciated.

One of us (H.M.S.) would like to express his gratitude to the IAEA for a fellowship.

(Received February 28, 1961)

\section{REFERENCES}

(1) T. Ishimori, H. M. SAMmour : This Journal, 3, No. 5, 344 352 (1961).

(2) P. A. SchulzE: Cited in L. I. Katzin Rept. TID.5223 (Pt-1), US. AEC Pap.-3.1 (1952).

(3) L. I. Katzin, R. W. Stoughton : ibid., Pap. -3.2 .

(4) F. L. Steahly, R. W. Stoughton : US. AEC Rept. CC-739, (1943).

(5) D. F. Ferguston, R. E. Leuze : ibid., ORNL371, (1950).

(6) J. R. Flanary: A/Conf., P/539, (1955).

(7) D. F. Peppard, G. W. Mason, M. V. Gergel: J. Inorg. Nucl. Chem., 3, 370 (1957).

(8) W. H. HARDWICK, M. MORETON-SMITH: Analyst, 83, 9 (1958).

(9) R. F. Clayton, W. H. Hardwick, M. MoreTON-SMITH: ibid., 83, 13 (1958).

(10) K. B. Brown, C. F. Colmmann, D. J. Crouse, C. A. Blake, A. D. Ryon: B/Conf., P/509, (1958). 
(11) T. H. Siddall: Abst. Pap. San Francisco Meeting of Am. Chem. Soc., 133, 14K (1958).

(12) A. VAN WINKLE, US. Patent-2,895,791, (1959).

(13) O. K. Neville: US.Patent-2,902,503, (1959).

(14) F. Ichikawa, S. Uruno: Bull. Chem. Soc Japan, 33, 569, (1960).

(15) I. L. JENKINS, R. J. RICHARDSON : $A E R E-C /$ $R \cdot 1217$, (1953).

(16) A. Chesne, P. Regnant : A/Conf., 8P/350, (1955).

(17) K. A. Kraus, G.E. Moore, F. Nelson: $J$. Am. Chem. Soc., 78, 2692 (1956).

(18) R. W. BANE: US. Patent-2,902,338, (1959).

(19) A. T. Gresky : US.AEC Rept. CF-56-2-157, (1956).

(20) B. J. Fontana: Cited in L. I. Katzin Rept. TID-5223 (Pt-1), US.AEC Pap.-3. 7 (1952).

(21) N. N. Hellmann, M. J. Wolf : ibid., Pap.-3. 11.

(20) F. Hagemann: ibid., Pap.-3.13.

(23) F. Hagemann, M. H. Studier, L. I. Katzin ibid., Pap.-3.15.

(24) E. K. Hyde, M. J. Wolf : ibid., Pap.-3. 12.

(25) C. E. Higgins, W. H. Baldwin, J. M. Ruth: US.AEC Rept. ORNL-1338, (Aug.14,1952).

(26) C. A. Blake, K. B. Brown, C. F. Colemann: ibid., ORNL.1964, (Nov. 17, 1955).

(27) L. L. Burger : J. Phys. Chem., 62, 590 (1958).

(28) C. D. Susano, H. S. House, M. A. Marler: US. AEC Rept. TID-7555, (1958).
(29) T. Ishimori, K. WATANABE, K Kimura; This Journal, 2, No. 12, 750 (1960).

(30) E. G. BahlmanN, et al. : Cited in L. I. Katzin Rept. - TID-5223(Pt-1), US.AEC Pap.-3. 8, (1952).

(1) A. S. Neuton, O. Johnson, W. Tuckr,

R. W. Fisher, H. LIPKIND : ibid., (Pt-2), Pap.8. 6.

(32) L. C. Craig: J. Biol. Chem., 155, 519 (1944); Anal. Chem., 22, 1346 (1950); L. C. CRAIG, W. Hausmann, E. H. Ahrens, Jr., E. HarfeNIST: ibid., 23, 1236 (1951).

(33) T. Ishimori, K. WAtanabe, T. Fujino: This Journal, 3, No. 1.19 (1961).

\section{放射性核種のカウンタ・カレント}

抽出分離, (II)

照射トリウムより ${ }^{23} \mathrm{U},{ }^{233} \mathrm{~Pa}$ の分離

石森富太郎, H.M. サムール

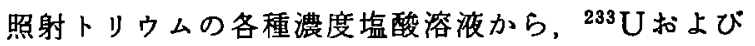

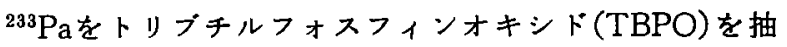
出剂として用い，クレイグ式カウンタ・カレント抽出 により分離を試みた。その結果，1\%TBPOートルェン に対しては，1N塩酸が最適であることがわかった。

この条件では，ウラン・フラクションの $D F$ むくく， プロトアクチニウムとトリウムの分離もよい。

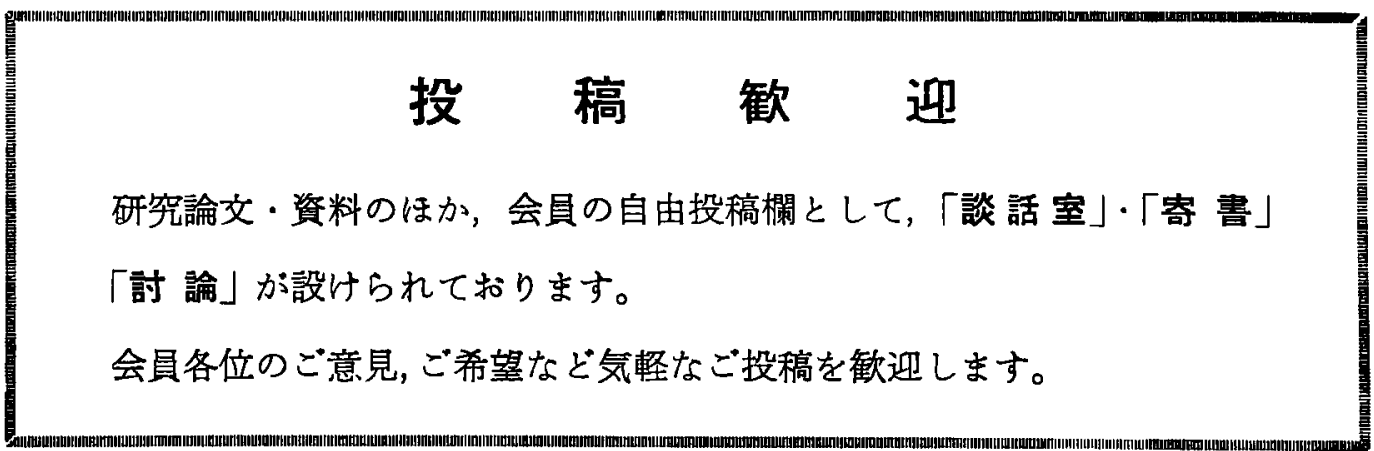

